Article

\title{
A Country-Specific Water Consumption Inventory Considering International Trade in Asian Countries Using a Multi-Regional Input-Output Table
}

\author{
Yuya Ono ${ }^{1, *}$, Young Deuk Kim ${ }^{2}$ and Norihiro Itsubo ${ }^{3}$ \\ 1 Institute of Industrial Science, University of Tokyo, Tokyo 153-8505, Japan \\ 2 Rural Research Institute, Korea Rural Community Corporation, Gyeonggi 426-908, Korea; \\ youngkim.kr@gmail.com \\ 3 Faculty of Environmental Studies, Tokyo City University, Yokohama 224-8551, Japan; Itsubo-n@tcu.ac.jp \\ * Correspondence: onoyuya@iis.u-tokyo.ac.jp; Tel.: +81-3-5452-6382
}

Received: 22 May 2017; Accepted: 27 July 2017; Published: 1 August 2017

\begin{abstract}
Interest in the impacts of water use in the life cycle of products and services are increasing among various stakeholders. The water footprint is a tool to identify critical and effective points for reducing the impact of water use through the entire life cycle of products, services, and organizations. The purpose of this study was to develop a water consumption inventory database that focused on identifying of Asian water consumption using an input-output (IO) framework. An Asia International Input-Output table (AIIO) was applied in this study. The amount of water consumption required for agricultural products was estimated by modeling; for other sectors it was estimated from statistical reports. The intensities of direct water consumption in each sector were calculated by dividing the amount of water consumption by the domestic production. Based on the IO analysis using Leontief's inverse matrix, the intensities of water consumption from cradle to gate were estimated for all goods and services. There was high intensity of water consumption in the primary industry sectors, together with a high dependency on rainwater as an input water source. The water consumption intensities generally showed a larger reduction in secondary sectors, in comparison with the tertiary sectors, due to the use of recycled water. There were differences between this study and previous studies due to the use of site-specific production data and the temporal resolution of crop production. By considering site-specific conditions, it is expected that the dataset developed here can be used for estimating the water footprint of products, services, and organizations in nine countries (Japan, South Korea, China, Taiwan, Thailand, the Philippines, Malaysia, Singapore, Indonesia, and USA).
\end{abstract}

Keywords: water footprint; Asia; water consumption; water resource types; inventory database; input-output analysis

\section{Introduction}

The quantity and quality of available freshwater is threatened by uneven distribution, increasing water demand, and emissions to freshwater resources due to worldwide population growth and changes in life style in developing countries (METI [1]; MLIT [2]). It has been reported by several studies that a lack of available freshwater, due to increasing freshwater consumption, will result in increased severity with regard to human health damage from malnutrition and infectious diseases (Pfister et al. [3]; Motoshita et al. [4]; Boulay et al. [5]; Motoshita et al. [6]), and with regard to ecosystem damage (Pfister et al. [3]; Verones et al. [7]; Van Zelm et al. [8]). The concept of a water footprint has been introduced by the Water Footprint Network (WFN) and the International Standardization Organization (ISO). In the manual published by the WFN, the goal of the water footprint assessment is defined as determining the impact of activities and products in terms of water scarcity and pollution 
by accounting for their direct and indirect water use, and investigating ways of moving towards more sustainable water use (Hoekstra et al. [9]). According to the ISO14046 standard (ISO 2014) [10], a water footprint quantifies the potential environmental impacts related to water. The scope of a water footprint assessment is: (a) to evaluate the environmental impacts of activities related to water use by accounting for inventory data (amount of freshwater consumed and emissions to water), and (b) to quantify the impacts throughout the life cycle of products, services, and organizations. Both aspects of such an assessment have a common underlying concept basically, to account for the amounts of direct and indirect water use related to the target products, services, organizations, and activities. Both WFN and ISO use quantitative indicators, but the phase of the assessment is different. The ISO methodology includes four phases: goal and scope, inventory accounting, impact assessment, and interpretation. This methodology aims at quantifying potential environmental impacts generated by human activities on a wide range of environmental issues (climate change, human respiratory impacts, land use, etc.). The WFN methodology addresses freshwater resource appropriation in a four-step approach, including setting goals and scope, water footprint accounting, sustainability assessment, and response formulation. The accounting phase includes the quantification and mapping of freshwater use with three distinct types of water use: blue, gray, and green water footprints. WFN aims to measure the human appropriation of freshwater resources that incorporates both direct and indirect water uses of a consumer or producer (Boulay et al. [11]; Manzardo et al. [12]). Several databases have been developed for the inventory analysis and impact assessment of a water footprint, and they have been used to support the implementation of specific case studies (Kobayashi and Oyasato [13]). In particular, inventory databases are essential for practitioners because of the great difficulties in collecting all the required inventory information for the variety of processes over the whole life cycle of a product or service.

The inventory databases in current use were developed by a bottom-up or an input-output (IO) analysis approach. In the bottom-up approach, the amount of energy, material, products, and the elementary flows related to the types of freshwater resources and emissions to freshwater resources are identified for each process and product. Several databases have been applied using this approach to establish a background database (The ecoinvent centre [14]; PE international [15]; Quantis [16]; Water Footprint Network [17]). While this approach has the advantage of incorporating reliable data, it requires a large quantity of resources (time, human effort, and cost) to cover all of the processes and products in a country or region. A lack of data for some processes and products will result in the loss of supply chain information, thus preventing the accounting of all water used throughout the entire supply chain that is used to underpin targets. In addition, physical flows of materials and energy are captured in the bottom-up approaches; however, these approaches may sometimes also lead to an underestimation of environmental loads in relation to services that require no direct input of physical material and energy, but are accompanied by monetary flows. The IO analysis approach is applied when developing an inventory database for life cycle assessment by many scholars (Lave et al. [18]; Suh and Huppes [19]; Nansai et al. [20,21]; Tukker et al. [22]; Blackhurst et al. [23]; Kim et al. [24]; Ono et al. [25]). The IO analysis describes the monetary transaction flow between sectors that accompanies purchased goods and services, by comprehensively covering all of the sectors in the target region. By assuming that the environmental loads of goods and services are proportional to the amounts involved in economic transactions, the amounts of environmental loads relevant to goods and services in each sector can be indirectly assigned and analyzed through whole supply chains.

Recently, studies have been conducted to develop an inventory database focused on the amount of freshwater used by referring to each country's IO table (Kobayashi and Oyasato [13]; Lenzen [26]; $\mathrm{Xu}$ et al. [27]; Blackhurst et al. [23]; Kim et al. [24]; Exiobase [28]; Ono et al. [25]). Ecoinvent 2.2 is a database developed using process analysis that includes temporal and geographical data. This database includes the water input intensity of around 4000 processes, with classification of the type of water resources. The previous databases developed for this purpose accounted for the withdrawal of freshwater from natural water streams and stocks without differentiating its use, defined as the 
amount returned to the original basin, and its consumption, defined as the amount that is not returned to the original basin. The fate of water after being withdrawn may critically affect the availability of freshwater for downstream users. In this context, a distinction of freshwater consumption in the elementary flow of a water footprint inventory analysis was highlighted in the guidelines published by the Water Footprint Network (Water Footprint Network [29]), the system of environmental economic accounting for water (UN United Nations [30]), and the ISO14046 (ISO 2014) [10]. In addition, the availability of freshwater from various resources will differ depending on the type of water resource (rain, surface water, groundwater, and others) and geographical location. Therefore, the types of water resource and geographical relevance need to be considered in the inventory database. Some inventory databases with detailed elementary flows (consumption and the types of water resources) have been developed by distinguishing between the forms of water use (input/consumption) and the types of water resources (The ecoinvent centre [14]; PE [15]; Quantis [16]; Water Footprint Network [17]); however, there is no database with a classification of the types of water resource (rain, surface water, and groundwater) and a multi-regional input-output table (MRIO).

The aim of this study was to develop a water consumption inventory database using the Asia International Input-Output table (AIIO). As the focus of the study was water consumption inventory in each type of water (rain water, surface water, and groundwater), grey water was not considered in this study. Relevant data were collected, and freshwater consumption estimates were made based on statistical data and model calculations, enabling the development of a water consumption inventory database to reflect Asia-specific conditions, water-use efficiency in production activities, climate conditions, etc. The comprehensiveness of existing databases was initially considered to establish an average water consumption database that was widely applicable to each Asian country's goods and services. Thus, the IO analysis was applied to cover all goods and services to produce an AIIO from 2005 covering all the industrial sectors of primary, secondary, and tertiary industries. Primary industry is defined as industry that is connected with obtaining or providing natural raw materials for conversion into commodities and products such as agriculture, forestry and fishery. Secondary industry is defined as an industry that converts raw materials into commodities and products for the consumer, such as manufacturing and construction industries. Tertiary industry is defined as an industry that provides services to consumers, such as other industries, except primary and secondary industries. In this study, comparison with the previous study was made, to analyze the characteristics of the newly developed database.

\section{Materials and Methods}

\subsection{Basic Concept, Definition of Elementary Flows}

In the ISO14046 standard, general elementary flows are defined as quantities of water, types of water resources, water quality parameters/characteristics, forms of water and their geographical location, temporal aspects, and emissions related to water quality [10]. The database developed in this study was designed to be applicable to the assessment of the physical availability of water footprint. Thus, the qualitative aspects were excluded from the target elementary flows in the database. The quantities of water in different forms were accounted for in accordance with the requirements in ISO14046, by distinguishing between the types of water resource according to their typical classification (rain, surface water, and groundwater). The forms of water use in this study were defined as in Ono et al. [25]. Water consumption was regarded as the amount of water taken from, but not returned to, the same drainage basin.

\subsection{Input-Output Table}

IO analysis depends on IO tables, which identify the interdependence between each industrial sector's economic situation at a specific point in time. In addition, MRIO tables are spatial representations of economies, and thus demonstrate the interconnections between industries in 
different counties. The Economic Research Institute for Association of Southeast Asian Nations (ASEAN) and East Asia (ERIA) constructed a detailed MRIO table referred to as the AIIO table [31]. The AIIO table covers 760 industrial sectors in 10 countries: Japan, South Korea, China, Taiwan, Thailand, the Philippines, Malaysia, Singapore, Indonesia, and USA. China provides statistics relating to the amounts of the different water types consumed; however, the statistics include Taiwanese data. Therefore, in the AIIO table, the Chinese and Taiwanese industrial sectors are integrated to represent one country.

To identify both the direct and indirect impacts of the water footprint in each industry, the individual components of the augmented MRIO table need to be recognised. In this study, the number of industrial sectors was expanded from 76 to 403 using the Japanese IO table and foreign trade statistics for comparison. Thus, the AIIO table used in this study referred to nine countries: Japan, South Korea, China, Thailand, the Philippines, Malaysia, Singapore, Indonesia, and USA, and a range of 760 to 1011 industrial sectors in each country. The AIIO can be used to analyse the economic, social, and environmental impacts within a supply chain.

\subsection{Water Consumption Calculations}

Assume that the size of the intermediate transactions matrix $\mathrm{T}$ is $\mathrm{N} \times \mathrm{N}$, where $\mathrm{N}$ is the row and column dimension of the $\mathrm{T}$ matrix. The intermediate transactions matrix is the basic table of the IO system, which records all production flows within the economy. The final demand matrix y is $\mathrm{N} \times \mathrm{K}$. The final demand is the amount of goods and services by each sector to final markets for their production, such as personal consumption purchases and sales to the government. Then, the total gross output $x$ of an economy can be calculated as follows:

$$
\mathrm{x}=\mathrm{T} 1^{\mathrm{N}}+\mathrm{y} 1^{\mathrm{K}}
$$

where $1^{\mathrm{N}}$ and $1^{\mathrm{K}}$ are row summation operators of sizes $\mathrm{N} \times 1$ and $\mathrm{K} \times 1$, respectively. The size of $\mathrm{x}$ is $\mathrm{N} \times 1$. To calculate the proportion, $\mathrm{A}$, of inputs purchased by each industry, each element of the transactions matrix, $\mathrm{T}$, was divided by the total output $\mathrm{x}$ of the receiving sector, as $\mathrm{A}=\mathrm{Tx}^{-1}$, where the hat symbol represents the diagonalization of the total output matrix and $\mathrm{A}$ is the matrix of input coefficients. The IO equation is obtained by substituting $\mathrm{T}=\mathrm{Ax}$ into Equation (1), and applying simple matrix operations to obtain the following:

$$
\mathrm{x}-\mathrm{Ax}=\mathrm{y} \Leftrightarrow(\mathrm{I}-\mathrm{A}) \mathrm{x}=\mathrm{y} \Leftrightarrow \mathrm{x}=(\mathrm{I}-\mathrm{A})^{-1} \mathrm{y}
$$

where $\mathrm{I}$ is the identity matrix, and $(\mathrm{I}-\mathrm{A})^{-1}$ is the Leontief inverse, which includes all direct and indirect impacts between different economic sectors and, thus, counts the total impact across all supply chains (Leontief [32,33]).

The fundamental IO theory was extended to include physical indicators such as any economic stimulus and water consumption. The direct water consumption of each industry per dollar is calculated similarly to the calculation of $\mathrm{A}$. The direct impacts are calculated as $\mathrm{d}=\mathrm{Qx}^{-1}$, where $\mathrm{Q}$ is the amount of water consumption.

The size of $Q$ is computed by the multiplication of $P \times N$, where $P$ is the row dimension of four indicators (rainwater, surface water, groundwater, and total water consumption). The $\mathrm{d}$ matrix provides the direct water consumption intensities. The total (direct + indirect) water consumption intensities can be counted as $\mathrm{e}=\mathrm{d}(\mathrm{I}-\mathrm{A})^{-1}$, where $\mathrm{e}$ is the multiplier that contains the total direct and indirect water consumption intensity. Total water consumption is obtained as $\mathrm{w}=\mathrm{ey}$, where $\mathrm{w}$ is the multiplier that contains the water consumption intensities and final demand. Here, $\mathrm{d}$ and $\mathrm{y}$ are a diagonal matrix, and the size of the matrix is $\mathrm{N} \times \mathrm{N}$. 


\subsection{Water Consumption Data Sources}

Water consumption was divided into primary, secondary and tertiary industries.

Water consumption data for primary industry were obtained from the literature (Mekonnen and Hoekstra [34]; FAO [35-38]; USGS [39]). In secondary industry, we estimated water consumption using AQUASTAT [38] and the water consumption rate given by Ono et al. [25]. Tertiary industry data were obtained from the literature (USGS [39]; FAO [40]).

Details of the water consumption of Japan and Korea were obtained from Ono et al. [25] and Kim et al. [24], respectively. More details, including an explanation of the theoretical origin and introduction of the data treatment procedure can be found in the literature (Ono et al. [25]; Kim et al. [24]) and are, therefore, not presented here in details. Details of the water consumption of other countries were obtained by the supporting information (See Supplementary Materials).

\section{Results}

\subsection{Estimated Freshwater Consumption in Each Industrial Sector and the Type of Water}

The total freshwater consumption was estimated based on the volume of direct freshwater used and the annual production of each sector. These were broken down into industrial sector and type of water resource as shown in Figures 1 and 2.

The water consumption of Indonesia (AI) was 964.9 billion $\mathrm{m}^{3}$, Malaysia (AM) was 308.9 billion $\mathrm{m}^{3}$, the Philippines (AP) was 197.3 billion $\mathrm{m}^{3}$, Singapore (AS) was 1.5 billion $\mathrm{m}^{3}$, Thailand (AT) was 177.5 billion $\mathrm{m}^{3}$, China (AC) was 2597 billion $\mathrm{m}^{3}$, Korea (AK) was 42.6 billion $\mathrm{m}^{3}$, Japan (AJ) was 77.9 billion $\mathrm{m}^{3}$, and USA (AU) was 1112 billion $\mathrm{m}^{3}$. Most water was consumed by primary industry, followed by secondary and tertiary industry, except for Singapore. In the case of Singapore, the tertiary sector accounted for $70 \%$ of water consumption, with the secondary industry having the next highest consumption. Rainwater was the predominant type of water consumed, followed by surface water and groundwater, except for Singapore where a large amount of water was used for agriculture and silviculture. Among the primary industries, the silvicultural sector dominated in each country. Water consumption was calculated by evapotranspiration in the silvicultural and agricultural sector; however, silviculture consumed only rainwater as input water. Therefore, when focusing on the type of water consumed, the impact of rainwater was large. In the case of Singapore, surface water was the predominant type of water consumed, followed by groundwater and rainwater.

Water use in the primary sector was 10 to 100 times higher than in secondary industry because secondary industry used recycled water (e.g., boiler water and raw water), which resulted in a low water consumption. In the secondary sector, surface water was the predominant type of water resource used, followed by groundwater.

In the tertiary industry, only tap water from the water supply industry (indirect input from water resources) was consumed. Because tap water is used as drinking water, the consumption depends on the population. Thus, countries with a high population (e.g., China and USA) had high water consumption. The trends in the type of water resource used were similar to those in the secondary industry.

Although agriculture is not a large activity in Singapore, high value-added manufacturing, as well as finance, information \& communication, and distribution services have been developed. Therefore, despite Singapore being located in the Asia monsoon zone with high temperatures and humidity, there was a low level of water consumption in its primary industry and little use of rainwater. There are few water resources in Singapore and a lack of space for cultivation. 


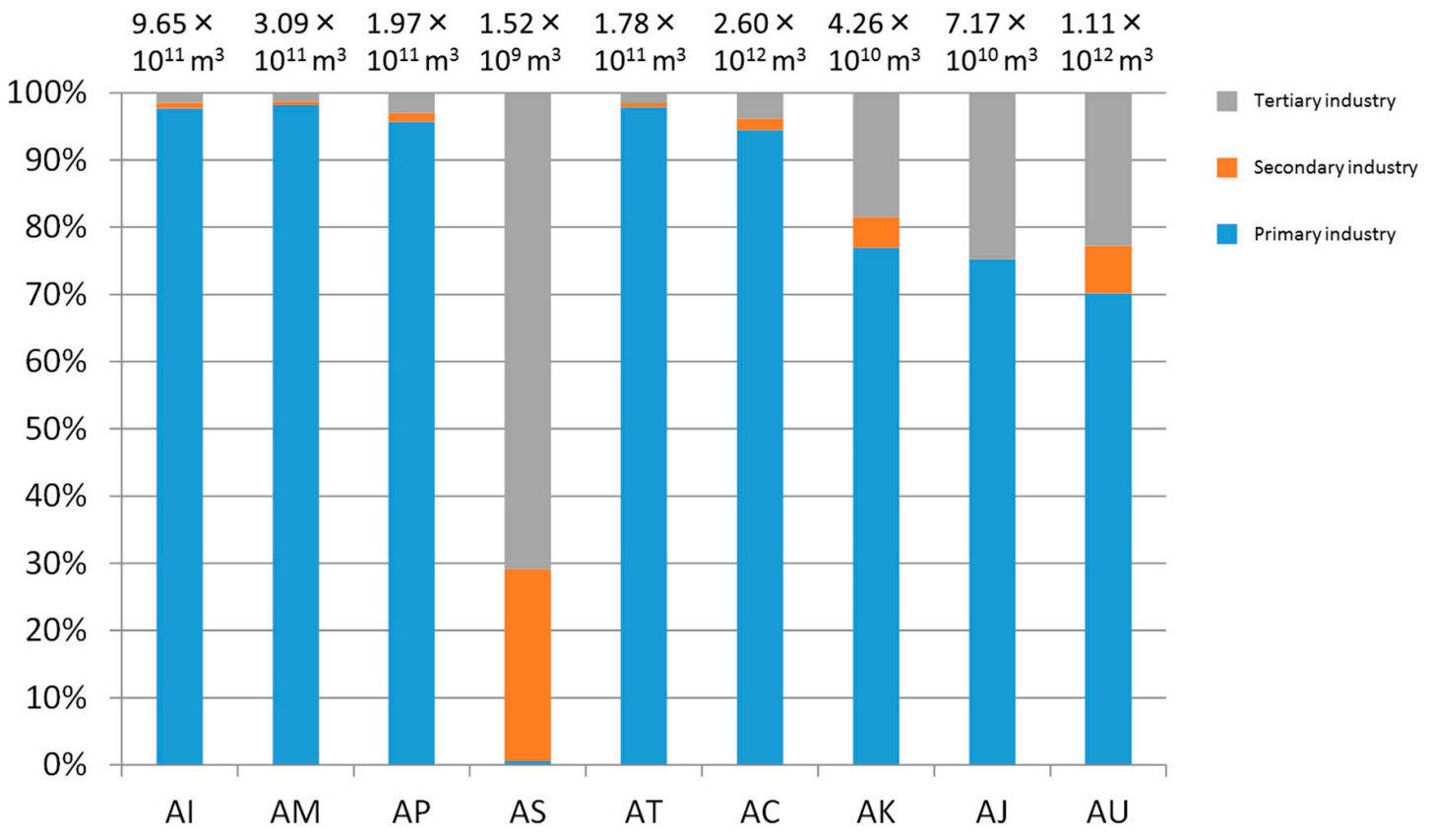

Figure 1. Water consumption in each industrial sector [Indonesia (AI), Malaysia (AM), the Philippines (AP), Singapore (AS), Thailand (AT), China (AC), Korea (AK), Japan (AJ), and USA (AU)].

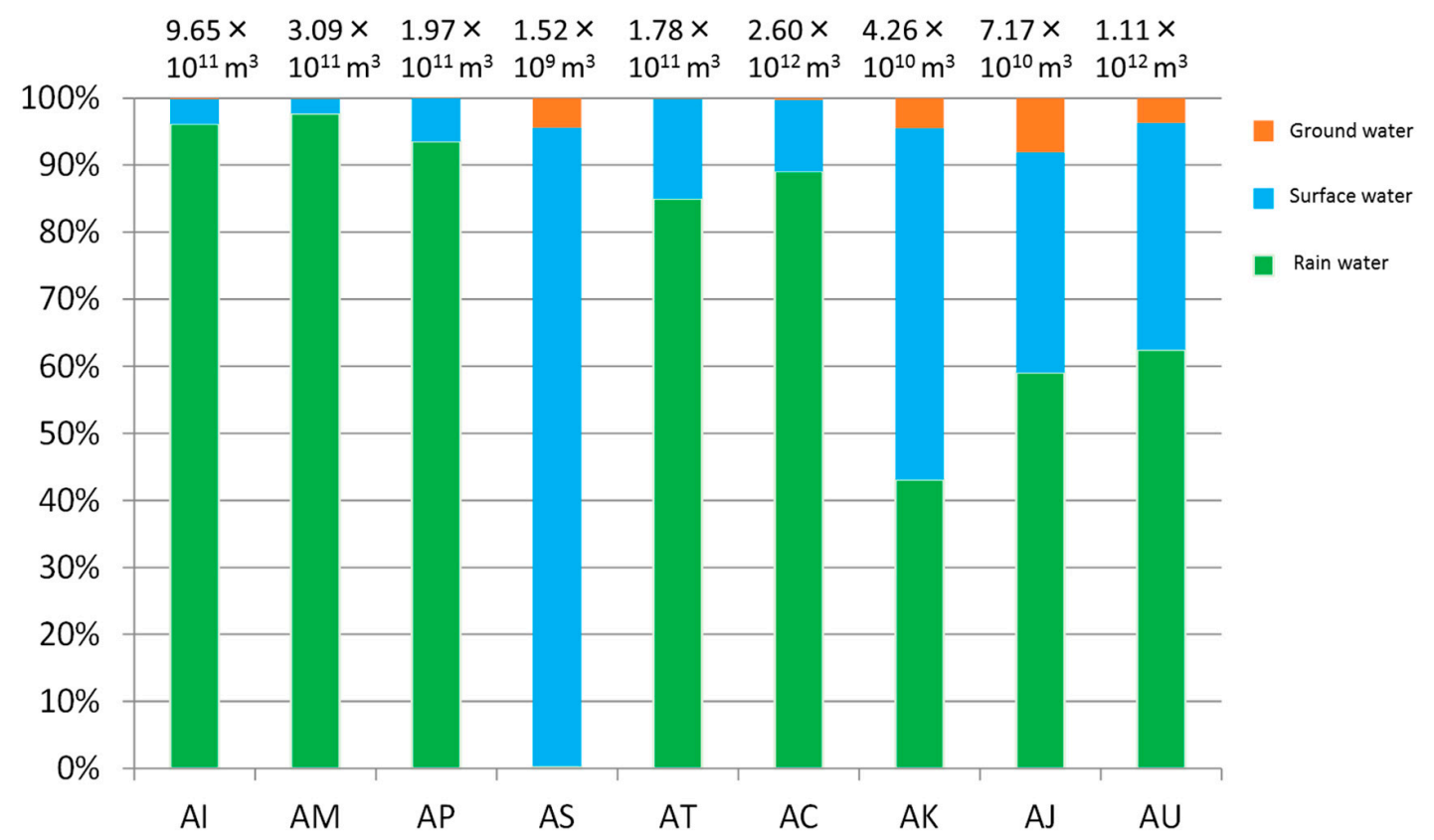

Figure 2. Type of water resource consumed [Indonesia (AI), Malaysia (AM), the Philippines (AP), Singapore (AS), Thailand (AT), China (AC), Korea (AK), Japan (AJ), and USA (AU)].

\subsection{Water Consumption Intensity}

Based on the direct freshwater consumption intensity value, the indirect freshwater consumption associated with the use of materials and energy was calculated for each process using an IO analysis. Figure 3 shows the freshwater consumption intensities, including both direct and indirect effects for all 760 sectors. The intensity value indicates the volume of freshwater consumption per unit production, expressed as $\mathrm{m}^{3} / 1000 \mathrm{US} \$$. 


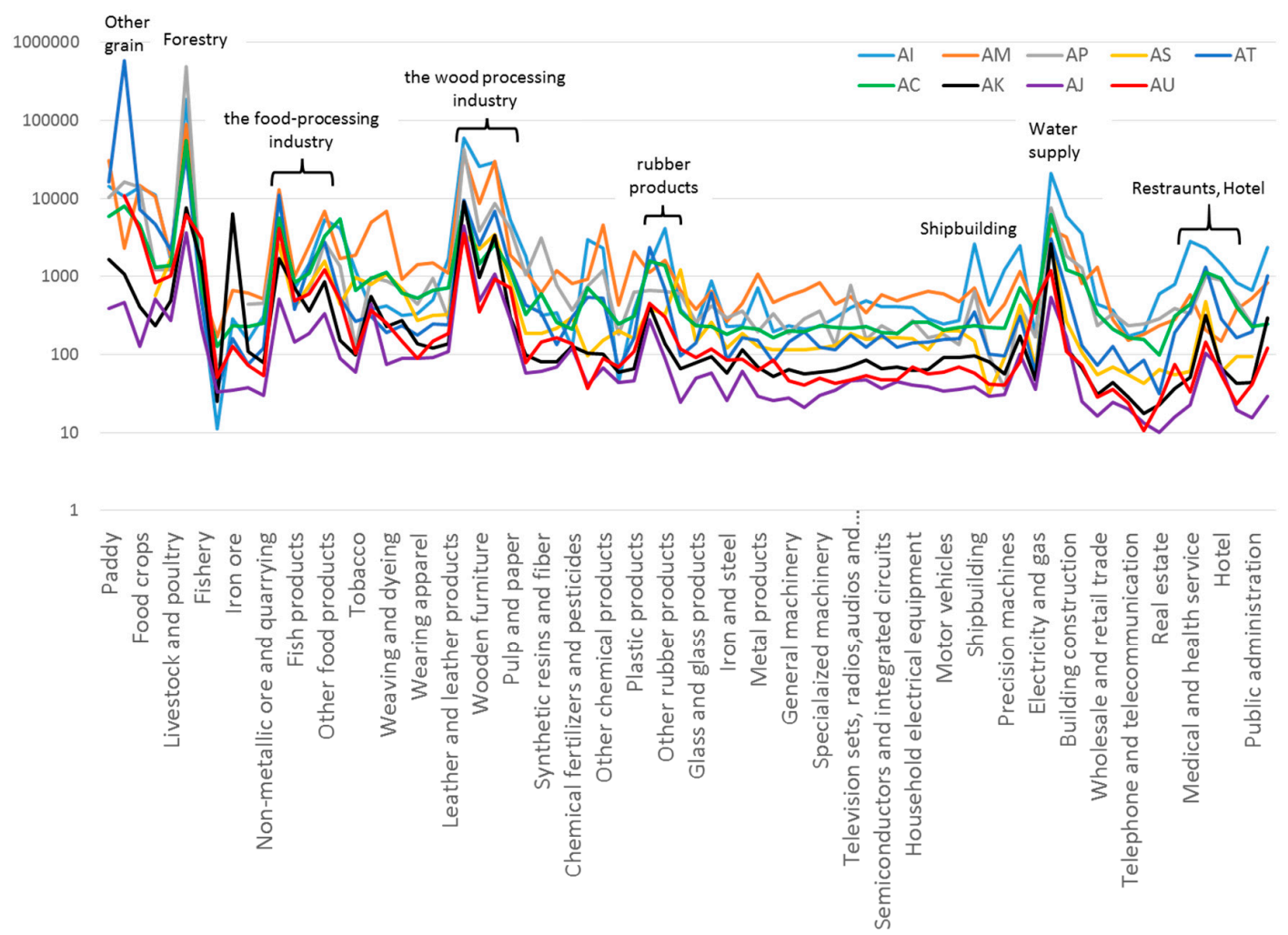

Figure 3. Intensities of water consumption by industrial sector [Indonesia (AI), Malaysia (AM), the Philippines (AP), Singapore (AS), Thailand (AT), China (AC), Korea (AK), Japan (AJ), and USA (AU)].

The intensities of total freshwater consumption in primary industry were generally larger than those of the secondary and tertiary sectors. The forestry sector had the largest water consumption per unit production in each country, due to the extensive practice area, long cultivation period, and low production value compared with other primary industries. Forestry water consumption intensities in the subtropical areas of the Philippines, Thailand, and Indonesia were higher than in Japan, Korea, and USA. In particular, the Philippine's forest industry water consumption intensity $\left(7.5 \times 10^{4} \mathrm{~m}^{3} / 1000\right.$ US\$) was higher by approximately 4-20-fold than in the forest sector in Japan $\left(3.7 \times 10^{3} \mathrm{~m}^{3} / 1000\right.$ US\$), Korea $\left(7.6 \times 10^{3} \mathrm{~m}^{3} / 1000\right.$ US\$), and USA $\left(1.7 \times 10^{4} \mathrm{~m}^{3} / 1000\right.$ US\$). Many other industrial sectors had high volumes of freshwater consumption per unit production, including paddy rice, cereals, and food crops. Consumption differed from country to country because of the different types of crops, cultivation areas, evapotranspiration rates, production values, etc. Therefore, the water consumption intensity of grain production in Thailand $\left(5.9 \times 10^{5} \mathrm{~m}^{3} / 1000\right.$ US\$) was higher than the water consumption intensity of forestry in Thailand $\left(4.7 \times 10^{4} \mathrm{~m}^{3} / 1000\right.$ US\$).

The water consumption intensity per production value in secondary industry was lower than the intensity in primary industry. Secondary industries use both freshwater and seawater, but this study focused on the use of freshwater. In addition, recovered water was reused many times. Surface water was the predominant source of water in these industries (see Section 3.1). However, some sectors within the secondary industry (e.g., food processing, wood processing, rubber products, and ship building), used raw materials from agriculture and forestry, and had higher water consumption intensity per production value than other sectors within the secondary and tertiary sectors. The Philippines, Thailand, Indonesia, Malaysia, and China had high water consumption values per unit production in their secondary industry. The Philippines, Thailand, Indonesia, Malaysia, and Singapore consumed large amounts of water, although their average production values were relatively low $\left(2.2 \times 10^{6}\right.$, $4.7 \times 10^{6}, 4.5 \times 10^{6}, 4.2 \times 10^{6}$, and $2.6 \times 10^{6}$ (1000 US\$), respectively). China and USA consumed 
huge amounts of water, while their average production values were relatively high $\left[6.9 \times 10^{7}\right.$ and $1.0 \times 10^{8}$ (1000 US\$, respectively)]. Japan and Korea consumed large amounts of water, while their average production values were relatively high $\left(6.0 \times 10^{7}\right.$ and $1.9 \times 10^{7}$ (1000 US\$), respectively).

In the tertiary sector, water consumption in the water supply sector was larger than in the tertiary sectors of industry. In addition, some sectors related to the water supply sector of industries (especially restaurants and hotels) also had high water consumption intensities.

\subsection{Amount of Water Consumption Considering International Trade}

Water consumption in each country were shown in Figures 4-7. These figures were separated by each type of water: total water consumption, rainwater, surface water, and ground water. According to Equation (1), total water consumption in each country were multiplied between water consumption intensity and final demand. Thus, water consumption in each country included domestic and import/export effects. In the case of the abscissa axis and vertical axis being the same, this represents domestic water consumption, and other axes represent import from each country.

The country with the largest water consumption was USA with about 2800 billion $\mathrm{m}^{3}$, followed by China (about 2100 billion $\mathrm{m}^{3}$ ), Indonesia (about 800 billion $\mathrm{m}^{3}$ ), Japan (about 300 billion $\mathrm{m}^{3}$ ), the Philippines (about 210 billion $\mathrm{m}^{3}$ ), Thailand (about 160 billion $\mathrm{m}^{3}$ ), Malaysia (about 110 billion $\mathrm{m}^{3}$ ), Korea (about 110 billion $\mathrm{m}^{3}$ ), and Singapore (about 20 billion $\mathrm{m}^{3+)}$ (Figure 4). The rate of domestic consumption was large (84-98\%) in Indonesia, Malaysia, Thailand, China, and USA. In Singapore, Korea, and Japan the rate of domestic consumption ranged from 4.4 to $38 \%$. In most countries, domestic water consumption was larger than other sources of consumption. In Singapore, the rate of domestic water consumption was low, because of the restricted land area available for manufacturing and industry, and imports of many products and services from other countries. Korea and Japan import raw materials from other countries, and export final products (e.g., motor vehicles) after manufacturing them. Primary sectors usually consumed large amounts of water, while the manufacturing industry consumed less. Therefore, the water consumption in these countries was lower than the one in other countries.

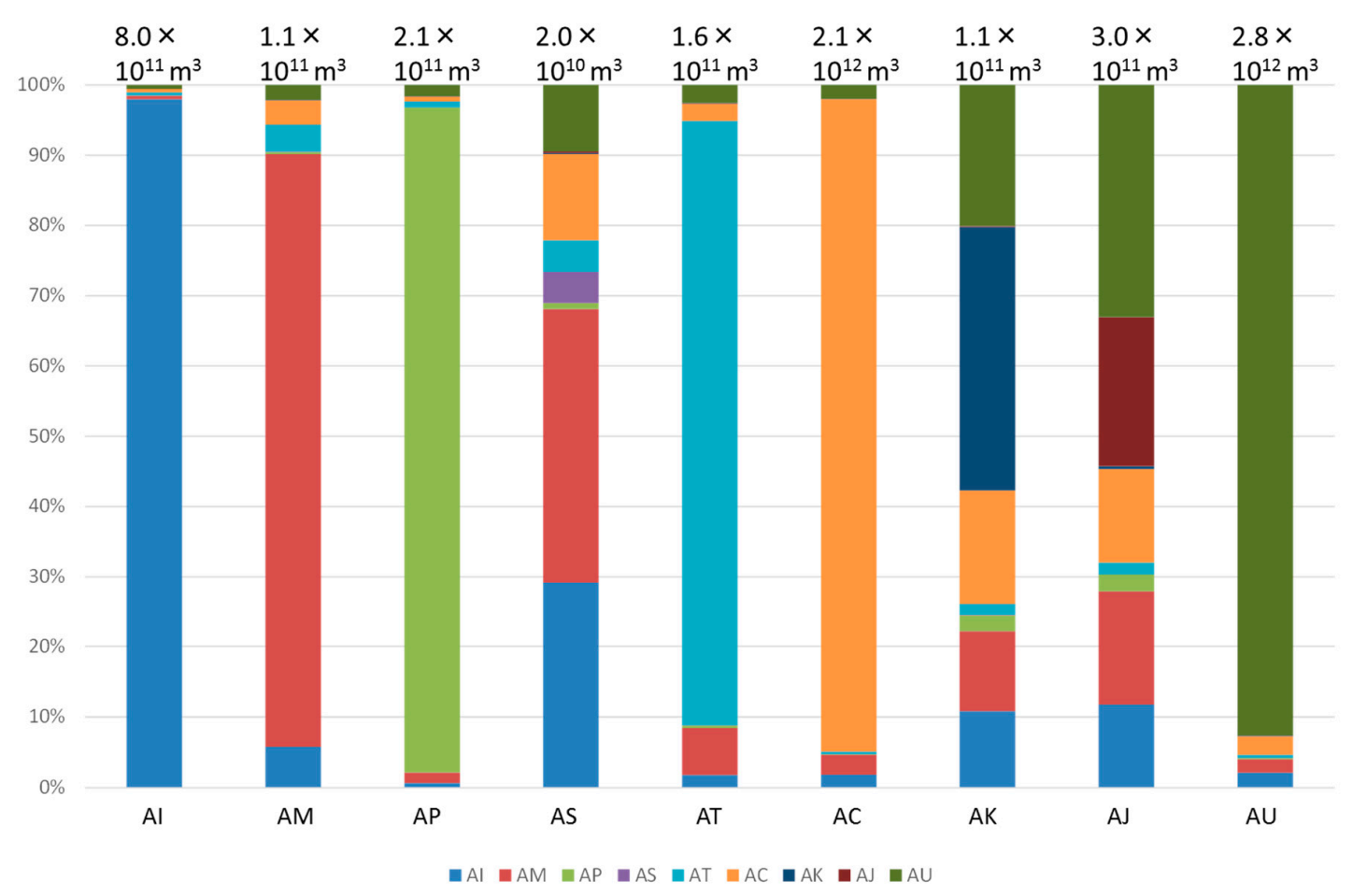

Figure 4. Water consumption in each country. [Indonesia (AI), Malaysia (AM), the Philippines (AP), Singapore (AS), Thailand (AT), China (AC), Korea (AK), Japan (AJ), and USA (AU)]. 
The consumption of rainwater accounted for about $73-95 \%$ of total water consumption in each country, and was mainly affected by the extent of the agriculture and forestry sectors (Figure 5). In each country, agriculture and timber were responsible for large consumption rates of rainwater. Forestry consumes huge amounts of rainwater due to its high evapotranspiration. Surface water and groundwater accounted for about $4-24 \%$ and $0-3 \%$ of total water consumption in each country, and were more important water sources for domestic consumption than rainwater (Figures 6 and 7). In Korea and Japan, surface water accounted for $55-78 \%$ and $64-69 \%$ of the total domestic consumption, while rainwater only accounted for about $20 \%$. The domestic water supply relied on withdrawals from surface water and groundwater, while rainwater was more commonly used by industry.

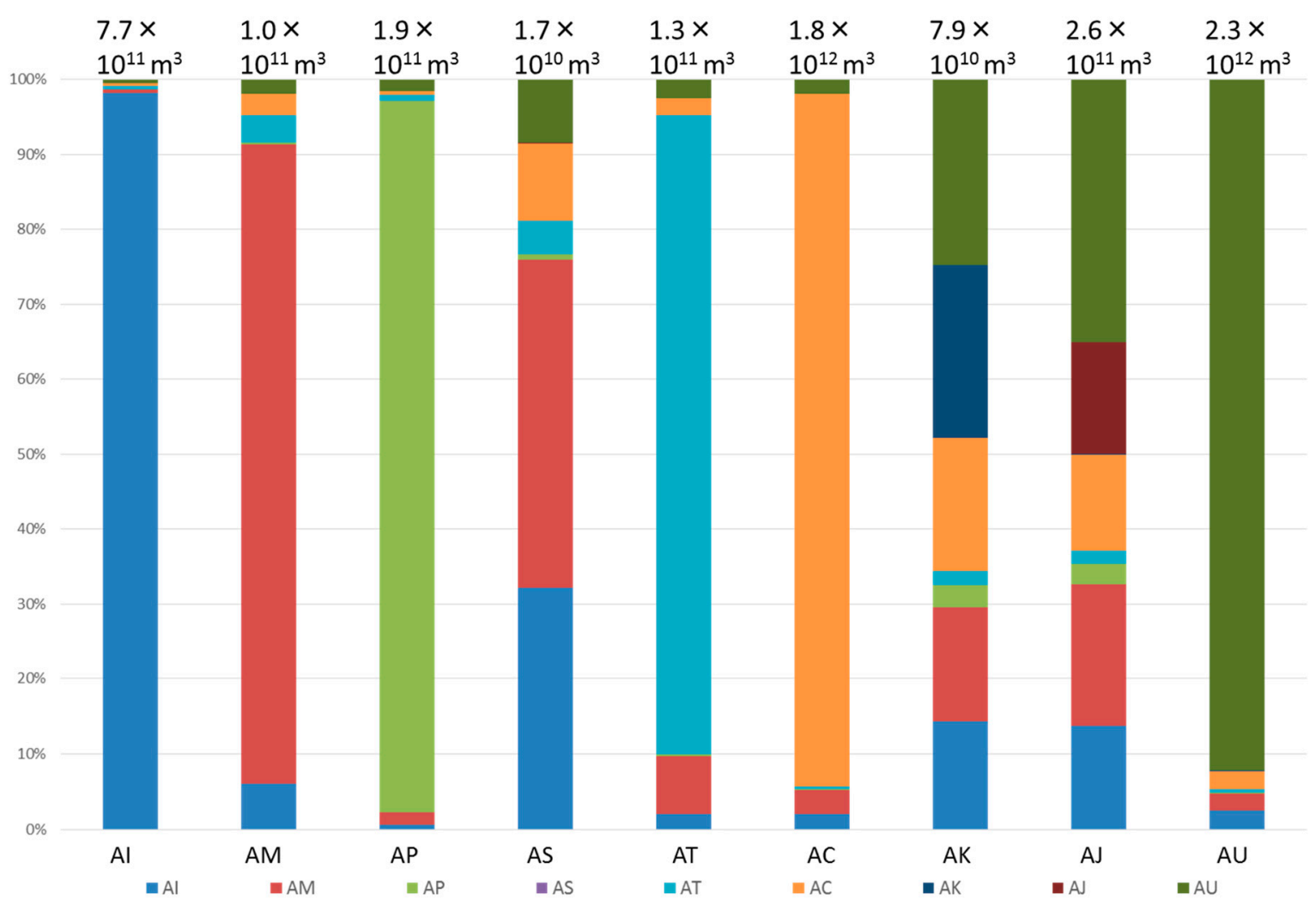

Figure 5. Rainwater consumption in each country. [Indonesia (AI), Malaysia (AM), the Philippines (AP), Singapore (AS), Thailand (AT), China (AC), Korea (AK), Japan (AJ), and USA (AU)]. 


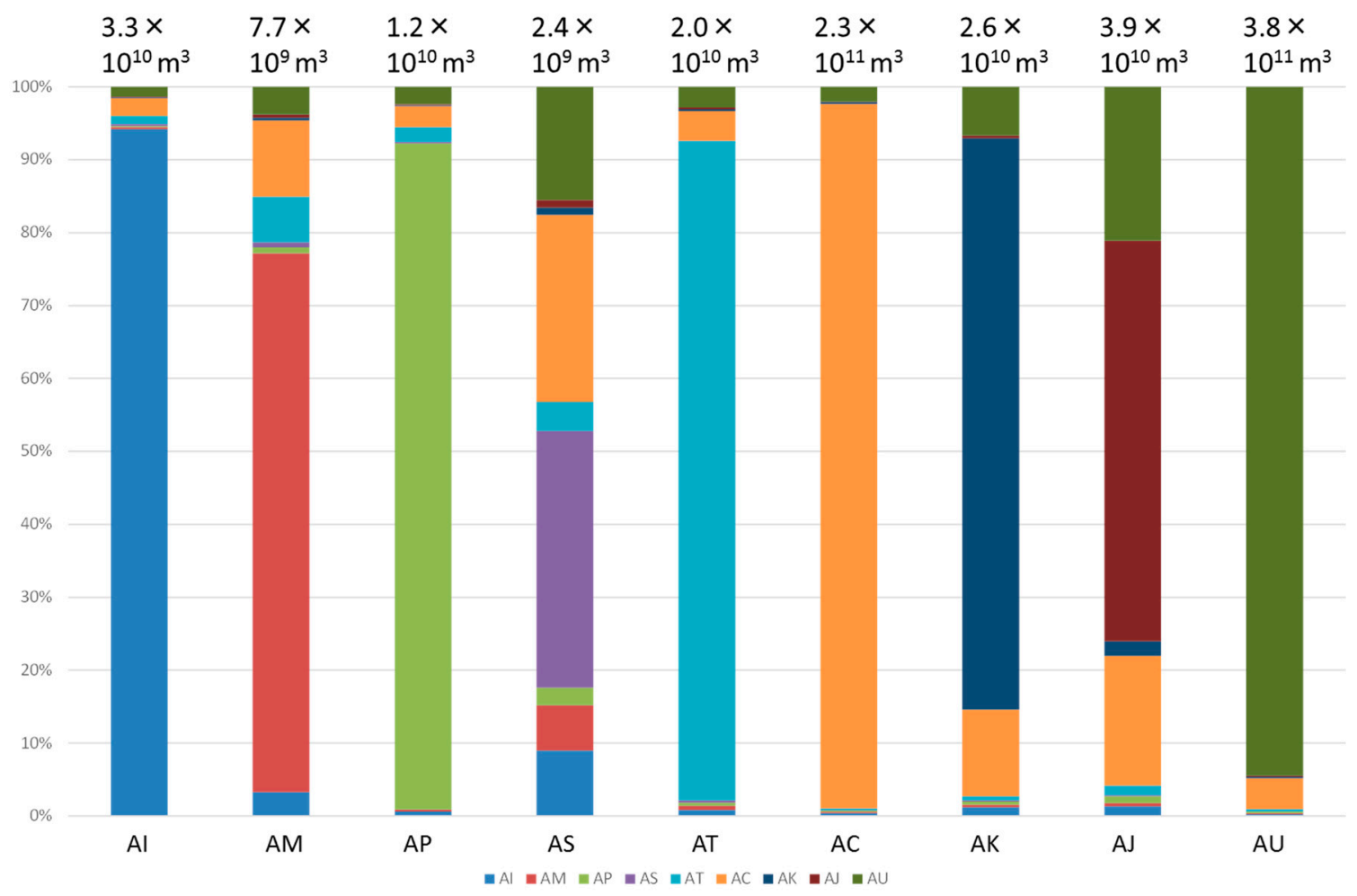

Figure 6. Surface water consumption in each country. [Indonesia (AI), Malaysia (AM), the Philippines $(\mathrm{AP})$, Singapore (AS), Thailand (AT), China (AC), Korea (AK), Japan (AJ), and USA (AU)].

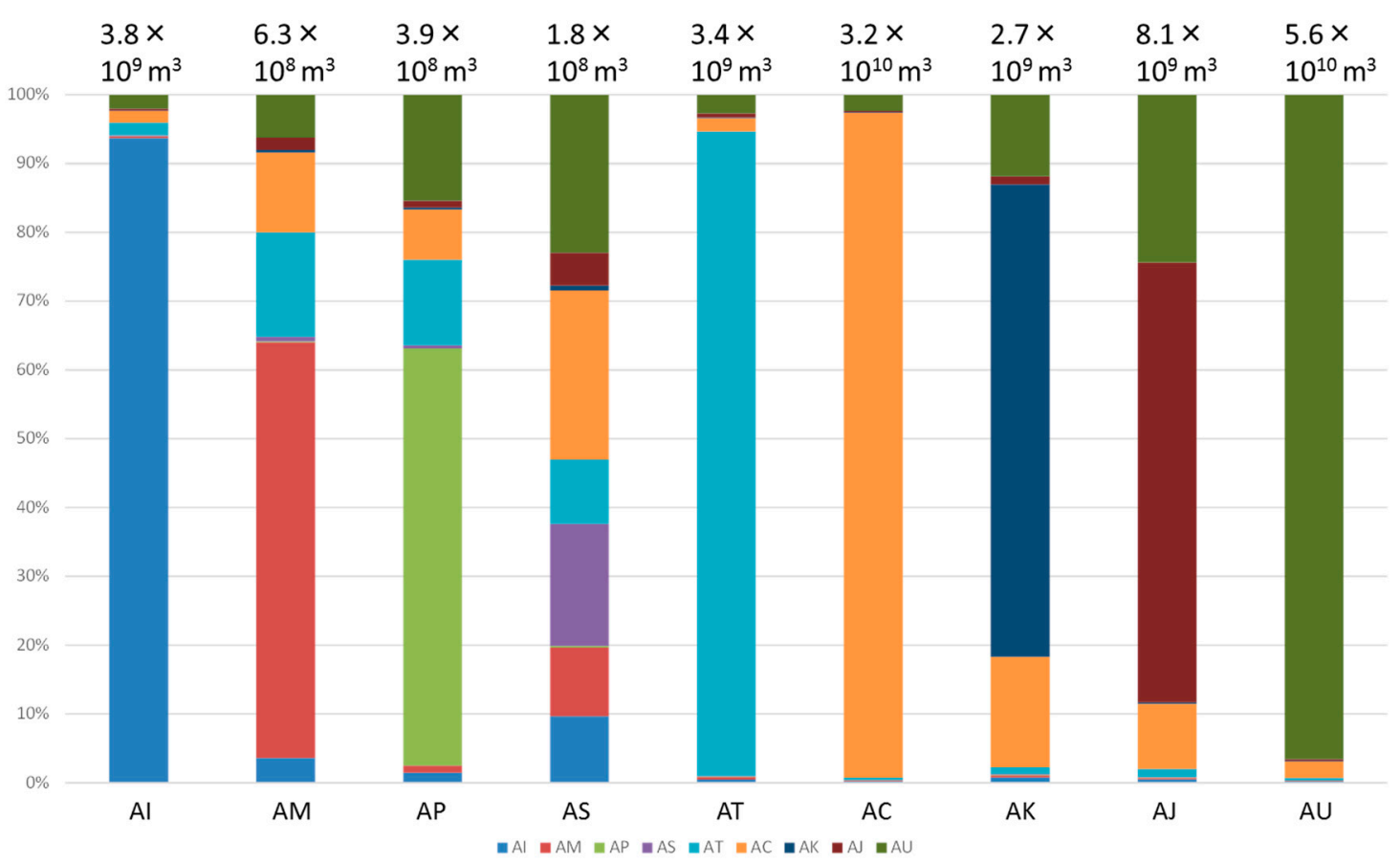

Figure 7. Groundwater consumption in each country. [Indonesia (AI), Malaysia (AM), the Philippines (AP), Singapore (AS), Thailand (AT), China (AC), Korea (AK), Japan (AJ), and USA (AU)]. 


\subsection{Sensitivity Analysis Focusing on Water Consumption of Nine Countries}

Sensitivity analysis of the water consumption was conducted out to examine geographical variation of the estimated water consumption. The water consumption by nine countries was calculated as follows:

$$
\text { Water consumption }=\sum\left(\mathrm{d}_{\mathrm{c}, \mathrm{i}} \times \mathrm{SR}_{\mathrm{c},} \times(\mathrm{I}-\mathrm{A})^{-1} \times \mathrm{F}_{\mathrm{c}, \mathrm{i}}\right)
$$

where $\mathrm{c}$ is the country, and $\mathrm{i}$ is the industry (e.g., primary, secondary and tertiary industry). SR is sensitivity rate, and $\mathrm{F}$ [1000 US\$] is final demand. As given, $\mathrm{d}\left[\mathrm{m}^{3} / 1000 \mathrm{US} \$\right]$ is the direct water consumption intensities; I is the identity matrix; and $(\mathrm{I}-\mathrm{A})^{-1}$ is the Leontief inverse. There are two scenarios as follows:

Scenario 1: SR is from 0.5 to 1.5 , and is applied to only one industry of all countries (Table 1).

Scenario 2 : SR is from 0.5 to 1.5 , and is applied to only primary industry of one country.

As per the results of Scenario 1, total water consumption of nine countries were from $9.6 \times 10^{12} \mathrm{~m}^{3}$ to $3.6 \times 10^{12} \mathrm{~m}^{3}$, and the difference of each result and base figure were from $3.0 \times 10^{12} \mathrm{~m}^{3}$ to $-3.0 \times 10^{12} \mathrm{~m}^{3}$. As most water was consumed by primary industry, the effect of SR on the primary industry was huge. Compared with base figure (BASE: SR is 1), the effect of SR on primary industry was in the range of $\pm 46 \%$. Indonesia (AI) was $\pm 49 \%$, Malaysia (AM) was $\pm 47 \%$, the Philippines (AP) was $\pm 48 \%$, Singapore (AS) was $\pm 45 \%$, Thailand (AT) was $\pm 49 \%$, China (AC) was $\pm 47 \%$, Korea (AK) was $\pm 45 \%$, Japan (AJ) was $\pm 46 \%$, and USA (AU) was $\pm 46 \%$. The SR effect on secondary industry was $\pm 1 \%$ and for the tertiary industry, it was $\pm 7 \%$ because direct water consumption of these industries were much lower than for the primary industries.

Table 1. Result of the sensitivity analysis in the primary industry for Scenario 1. (BASE means SR $=1$,

Primary industry (Pri), Secondary industry (Sec) and Tertiary industry (Tar)).

\begin{tabular}{|c|c|c|c|c|c|c|c|c|c|c|c|c|}
\hline & Total & Difference & AI & AM & AP & AS & AT & $\mathrm{AC}$ & AK & AJ & AU & Total \\
\hline 1.5-Pri & $9.6 \times 10^{12}$ & $3.0 \times 10^{12}$ & $149 \%$ & $147 \%$ & $148 \%$ & $145 \%$ & $149 \%$ & $147 \%$ & $145 \%$ & $146 \%$ & $143 \%$ & $146 \%$ \\
\hline 1.5-Sec & $6.6 \times 10^{12}$ & $7.1 \times 10^{10}$ & $100 \%$ & $101 \%$ & $101 \%$ & $102 \%$ & $100 \%$ & $101 \%$ & $101 \%$ & $101 \%$ & $102 \%$ & $101 \%$ \\
\hline 1.5-Tar & $6.8 \times 10^{12}$ & $2.2 \times 10^{11}$ & $101 \%$ & $102 \%$ & $101 \%$ & $104 \%$ & $101 \%$ & $102 \%$ & $104 \%$ & $104 \%$ & $105 \%$ & $103 \%$ \\
\hline 1.4-Pri & $9.0 \times 10^{12}$ & $2.4 \times 10^{12}$ & $139 \%$ & $138 \%$ & $139 \%$ & $136 \%$ & $139 \%$ & $138 \%$ & $136 \%$ & $136 \%$ & $135 \%$ & $137 \%$ \\
\hline 1.4-Sec & $6.6 \times 10^{12}$ & $5.7 \times 10^{10}$ & $100 \%$ & $100 \%$ & $100 \%$ & $101 \%$ & $100 \%$ & $101 \%$ & $101 \%$ & $100 \%$ & $101 \%$ & $101 \%$ \\
\hline 1.4-Tar & $6.7 \times 10^{12}$ & $1.7 \times 10^{11}$ & $101 \%$ & $102 \%$ & $101 \%$ & $103 \%$ & $101 \%$ & $102 \%$ & $103 \%$ & $103 \%$ & $104 \%$ & $103 \%$ \\
\hline 1.3-Tar & $6.7 \times 10^{12}$ & $1.3 \times 10^{11}$ & $101 \%$ & $101 \%$ & $101 \%$ & $102 \%$ & $101 \%$ & $101 \%$ & $102 \%$ & $102 \%$ & $103 \%$ & $102 \%$ \\
\hline 1.2-Pri & $7.8 \times 10^{12}$ & $1.2 \times 10^{12}$ & $119 \%$ & $119 \%$ & $119 \%$ & $118 \%$ & $119 \%$ & $119 \%$ & $118 \%$ & $118 \%$ & $117 \%$ & $118 \%$ \\
\hline $1.2-\mathrm{Sec}$ & $6.6 \times 10^{12}$ & $2.8 \times 10^{10}$ & $100 \%$ & $100 \%$ & $100 \%$ & $101 \%$ & $100 \%$ & $100 \%$ & $100 \%$ & $100 \%$ & $101 \%$ & $100 \%$ \\
\hline 1.2-Tar & $6.7 \times 10^{12}$ & $8.6 \times 10^{10}$ & $100 \%$ & $101 \%$ & $100 \%$ & $102 \%$ & $100 \%$ & $101 \%$ & $102 \%$ & $102 \%$ & $102 \%$ & $101 \%$ \\
\hline 1.1-Pri & $7.2 \times 10^{12}$ & $6.0 \times 10^{11}$ & $110 \%$ & $109 \%$ & $110 \%$ & $109 \%$ & $110 \%$ & $109 \%$ & $109 \%$ & $109 \%$ & $109 \%$ & $109 \%$ \\
\hline $0.9-\mathrm{Sec}$ & $6.6 \times 10^{12}$ & $-1.4 \times 10^{10}$ & $100 \%$ & $100 \%$ & $100 \%$ & $100 \%$ & $100 \%$ & $100 \%$ & $100 \%$ & $100 \%$ & $100 \%$ & $100 \%$ \\
\hline 0.9-Tar & $6.5 \times 10^{12}$ & $-4.3 \times 10^{10}$ & $100 \%$ & $100 \%$ & $100 \%$ & $99 \%$ & $100 \%$ & $100 \%$ & $99 \%$ & $99 \%$ & $99 \%$ & $99 \%$ \\
\hline 0.8-Pri & $5.4 \times 10^{12}$ & $-1.2 \times 10^{12}$ & $81 \%$ & $81 \%$ & $81 \%$ & $82 \%$ & $81 \%$ & $81 \%$ & $82 \%$ & $82 \%$ & $83 \%$ & $82 \%$ \\
\hline $0.8-\mathrm{Sec}$ & $6.5 \times 10^{12}$ & $-2.8 \times 10^{10}$ & $100 \%$ & $100 \%$ & $100 \%$ & $99 \%$ & $100 \%$ & $100 \%$ & $100 \%$ & $100 \%$ & $99 \%$ & $100 \%$ \\
\hline 0.8-Tar & $6.5 \times 10^{12}$ & $-8.6 \times 10^{10}$ & $100 \%$ & $99 \%$ & $100 \%$ & $98 \%$ & $100 \%$ & $99 \%$ & $98 \%$ & $98 \%$ & $98 \%$ & $99 \%$ \\
\hline 0.7-Pri & $4.8 \times 10^{12}$ & $-1.8 \times 10^{12}$ & $71 \%$ & $72 \%$ & $71 \%$ & $73 \%$ & $71 \%$ & $72 \%$ & $73 \%$ & $73 \%$ & $74 \%$ & $73 \%$ \\
\hline $0.7-\mathrm{Sec}$ & $6.5 \times 10^{12}$ & $-4.3 \times 10^{10}$ & $100 \%$ & $100 \%$ & $100 \%$ & $99 \%$ & $100 \%$ & $99 \%$ & $99 \%$ & $100 \%$ & $99 \%$ & $99 \%$ \\
\hline 0.7-Tar & $6.4 \times 10^{12}$ & $-1.3 \times 10^{11}$ & $99 \%$ & $99 \%$ & $99 \%$ & $98 \%$ & $99 \%$ & $99 \%$ & $98 \%$ & $98 \%$ & $97 \%$ & $98 \%$ \\
\hline 0.6-Pri & $4.2 \times 10^{12}$ & $-2.4 \times 10^{12}$ & $61 \%$ & $62 \%$ & $61 \%$ & $64 \%$ & $61 \%$ & $62 \%$ & $64 \%$ & $64 \%$ & $65 \%$ & $63 \%$ \\
\hline $0.6-\mathrm{Sec}$ & $6.5 \times 10^{12}$ & $-5.7 \times 10^{10}$ & $100 \%$ & $100 \%$ & $100 \%$ & $99 \%$ & $100 \%$ & $99 \%$ & $99 \%$ & $100 \%$ & $99 \%$ & $99 \%$ \\
\hline
\end{tabular}


As per the results of Scenario 2, the nine countries were classified into three types according to the industry characteristics and its effects on other countries.

Type 1: Indonesia (AI), Malaysia (AM), China (AC), and USA (AU)

Type 2: The Philippines (AP) and Thailand (AT)

Type 3: Singapore (AS), Korea (AK), and Japan (AJ)

Type 1 is characterized by a high production rate of primary industry products from own country, and they are export-oriented countries. In case of USA (Table 2), the range of water consumption was $\pm 40 \%$, and it affected Japan $( \pm 16 \%)$, Korea $( \pm 10 \%)$, Singapore $( \pm 4 \%)$, and others $( \pm 1 \%)$. Water consumption by China was $\pm 44 \%$, and it affected Japan $( \pm 6 \%)$, Korea $( \pm 7 \%)$, Singapore $( \pm 5 \%)$, and others $( \pm 1 \%)$. Water consumption by Malaysia was $\pm 40 \%$, and it affected Japan $( \pm 4 \%)$, Korea $( \pm 6 \%)$, Singapore $( \pm 19 \%)$, and others $( \pm 1 \%)$. Water consumption by Indonesia was $\pm 48 \%$, and it affected Japan $( \pm 6 \%)$, Korea $( \pm 5 \%)$, Singapore $( \pm 14 \%)$ and others $( \pm 3 \%)$. Type 2 countries occupied a high production rate of primary industry products from their own country. Thus, these countries only affected their own country. The water consumption of the Philippines was $\pm 46 \%$, and it affected others $( \pm 1 \%)$. Water consumption by Thailand was $\pm 42 \%$, and it affected others ( $\pm 2 \%)$. Type 3 countries had a low production rate of primary industry products from their own countries, and tended to affect other countries. The range of water consumption of Korea was $\pm 15 \%$, Japan was $\pm 8 \%$, and Singapore $(0 \%)$.

Table 2. Result of the sensitivity analysis in the primary industry of USA for scenario 2. [BASE means $\mathrm{SR}=1$, Primary industry (Pri), Secondary industry (Sec), Tertiary industry (Tar) and USA (AU)].

\begin{tabular}{|c|c|c|c|c|c|c|c|c|c|c|c|c|}
\hline & Total & Difference & AI & $\mathbf{A M}$ & AP & AS & AT & $\mathrm{AC}$ & AK & AJ & AU & Total \\
\hline 1.5-Pri-AU & $7.8 \times 10^{12}$ & $1.2 \times 10^{12}$ & $100 \%$ & $101 \%$ & $101 \%$ & $104 \%$ & $101 \%$ & $101 \%$ & $110 \%$ & $116 \%$ & $140 \%$ & $118 \%$ \\
\hline 1.4-Pri-AU & $7.5 \times 10^{12}$ & $9.5 \times 10^{11}$ & $100 \%$ & $101 \%$ & $101 \%$ & $103 \%$ & $101 \%$ & $101 \%$ & $108 \%$ & $113 \%$ & $132 \%$ & $114 \%$ \\
\hline 1.3-Pri-AU & $7.3 \times 10^{12}$ & $7.1 \times 10^{11}$ & $100 \%$ & $101 \%$ & $100 \%$ & $102 \%$ & $101 \%$ & $101 \%$ & $106 \%$ & $110 \%$ & $124 \%$ & $111 \%$ \\
\hline 1.2-Pri-AU & $7.1 \times 10^{12}$ & $4.8 \times 10^{11}$ & $100 \%$ & $100 \%$ & $100 \%$ & $102 \%$ & $100 \%$ & $100 \%$ & $104 \%$ & $106 \%$ & $116 \%$ & $107 \%$ \\
\hline 1.1-Pri-AU & $6.8 \times 10^{12}$ & $2.4 \times 10^{11}$ & $100 \%$ & $100 \%$ & $100 \%$ & $101 \%$ & $100 \%$ & $100 \%$ & $102 \%$ & $103 \%$ & $108 \%$ & $104 \%$ \\
\hline BASE & $6.6 \times 10^{12}$ & 0 & $100 \%$ & $100 \%$ & $100 \%$ & $100 \%$ & $100 \%$ & $100 \%$ & $100 \%$ & $100 \%$ & $100 \%$ & $100 \%$ \\
\hline 0.7-Pri-AU & $5.9 \times 10^{12}$ & $-7.1 \times 10^{11}$ & $100 \%$ & $99 \%$ & $100 \%$ & $98 \%$ & $99 \%$ & $99 \%$ & $94 \%$ & $90 \%$ & $76 \%$ & $89 \%$ \\
\hline 0.6-Pri-AU & $5.6 \times 10^{12}$ & $-9.5 \times 10^{11}$ & $100 \%$ & $99 \%$ & $99 \%$ & $97 \%$ & $99 \%$ & $99 \%$ & $92 \%$ & $87 \%$ & $68 \%$ & $86 \%$ \\
\hline 0.5-Pri-AU & $5.4 \times 10^{12}$ & $-1.2 \times 10^{11}$ & $100 \%$ & $99 \%$ & $99 \%$ & $96 \%$ & $99 \%$ & $99 \%$ & $90 \%$ & $84 \%$ & $60 \%$ & $82 \%$ \\
\hline
\end{tabular}

Primary industry could be observed by the sensitivity analysis. Details of the sensitive analysis can be referred in the supporting information (see Supplementary Materials).

\section{Discussion}

\subsection{Comparison with Previous Study and the Japanese Characteristics Identified in This Study}

A comparison of the Japanese total water consumption intensities ( $\mathrm{m}^{3} / 1000$ US\$) between this study and a previous study (Ono et al. [25]) was undertaken to determine the accuracy of this study. The number of industrial sectors in this study and Ono et al. [25] was about 400. According to Ono et al. [25], the indirect impact of technology from other countries is assumed to be approximately the same as that of Japanese technology.

Overall, the water consumption intensity in this study was about 2.4 times larger than the previous study by Ono et al. [25]. In the primary industry sector, there were few differences because the rate of domestic consumption was so large. However, some sectors (e.g., pig farming, beef cattle, sea fisheries, and marine aquaculture) were 1.5-2.4 times larger than the Ono's study, and these sectors were also affected by activities in other countries. For example, the beef cattle sector imported $68 \%$ of its raw materials (USA 37\%, The Philippines 13\%, China 11\%, Malaysia 4\%, Indonesia 1\%, and Thailand 1\%), mainly food crops and other grains. Secondary industrial sectors had relatively large differences in 
water consumption compared with the values for these industries in Ono et al. [25]. This was most apparent in the food processing sector (noodles were 4.2 times higher, flour and other grain milled products were 22.4 times higher, starch, dextrose, syrup and isomerized sugar were 25.6 times higher, vegetable oils and meal were 3.4 times higher, and beer was 3.1 times higher), the textile industry [fiber yarns were 4.8 times higher, cotton and staple fiber fabrics (including fabrics of synthetic spun fibers) were 7.0 times higher, woollen fabrics, hemp fabrics, and other fabrics were 4.1 times higher, and knitting fabrics were 4.3 times higher], and sectors related to timber or inedible crops [tires and inner tubes were 14.7 times higher, rubber footwear was 9.1 times higher, and "Tatami" (straw matting) and straw products were 3.7 times higher]. Most of these food-processing industries were located in USA (50-98\%), while the textile industries were mostly located in China (23-49\%) and USA (18-41\%), tires and inner tubes and rubber footwear were mostly located in Indonesia (49-62\%), and "Tatami" (straw matting), and straw products were mostly located in China (69\%) (Table 3). The total water consumption intensity in the tertiary industry sector was about 1.8 times larger than those in the Ono et al. study [25]. Compared with other industrial sectors, the tertiary sector had low water consumption intensity, and domestic use accounted for almost half of the total consumption.

It was clear that rainwater was the predominant source of water consumed, followed by surface water and groundwater. Ono et al. [25] reported a similar trend in the primary industry sector. However, in tertiary industry sectors, surface water dominated, followed by rainwater and groundwater (Ono et al. [25]). It was a common feature that inland water fisheries and aquaculture, the water supply industry, and industrial water use resulted in a high rate of surface water and groundwater abstraction because these sectors directly use surface water and groundwater rather than rainwater. In addition, these sectors accounted for more than $85 \%$ of direct water consumption, with some limited effects on other countries that received exported produce.

Table 3. Comparison between the results of this study and those of Ono et al. [25].

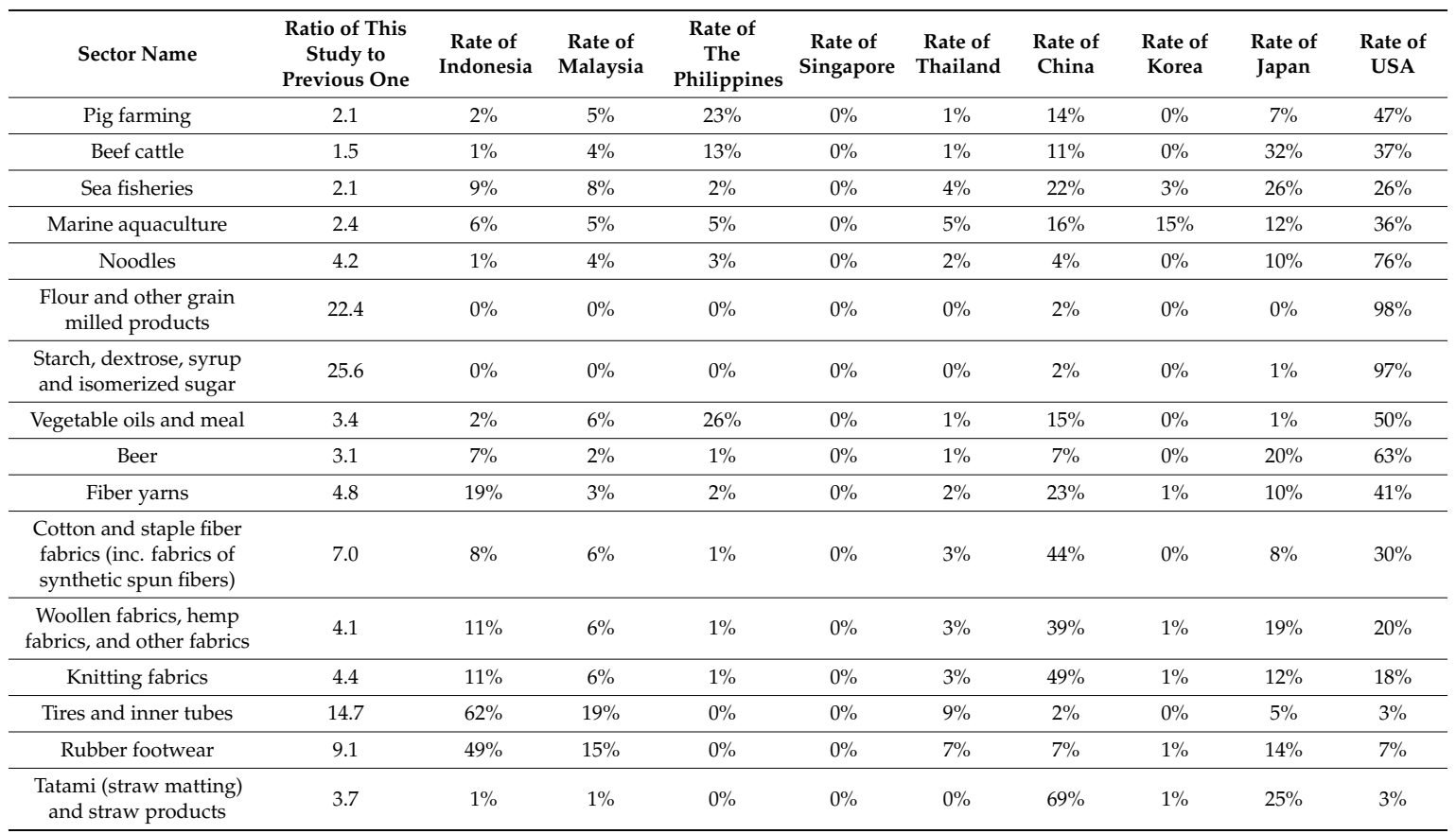

\subsection{Comparison between EXIOBASE Data and This Study}

We compared Compiling and Refining Environmental and Economic Accounts (CREEA) data (Tukker et al. [41]) and this study (see Section 3.3), with a focus on the water consumption of one country and one person (Table 4). The targets constituted USA, China, and Japan. We focused on only surface water and groundwater because CREEA data show surface water and groundwater. The 
CREEA data include the EXIOBASE database and cover 43 countries. The method for the calculation of water consumption is similar to that used in this study.

According to the CREEA data, the water consumption of Japan and one person are 36,398 million $\mathrm{m}^{3}$ and $285 \mathrm{~m}^{3}$, respectively. The corresponding figures for USA are 200,052 million $\mathrm{m}^{3}$ and $664 \mathrm{~m}^{3}$, respectively, and for China they are 239,967 million $\mathrm{m}^{3}$ and $182 \mathrm{~m}^{3}$, respectively. In contrast, this study showed that the water consumption of Japan and one person are 42,616 million $\mathrm{m}^{3}$ and $334 \mathrm{~m}^{3}$, respectively, while the corresponding figures for USA are 239,894 million $\mathrm{m}^{3}$, and $796 \mathrm{~m}^{3}$, respectively, and for China they are 229,880 million $\mathrm{m}^{3}$ and $174 \mathrm{~m}^{3}$, respectively. The data are shown in Table 2. In comparison with CREEA data, the values for Japan and USA were 1.2 times higher and the value for China was similar.

Table 4. Comparison between this study and CREEA data.

\begin{tabular}{ccccc}
\hline & & Number of People (Person) & Country (Million $\mathbf{~ m}^{\mathbf{3}}$ ) & One Person $\mathbf{( m}^{\mathbf{3}}$ ) \\
\hline \multirow{3}{*}{ This study } & Japan & $127,770,750$ & 42,616 & 334 \\
& USA & $301,231,207$ & 239,894 & 796 \\
& China & $1,317,885,000$ & 229,880 & 174 \\
\hline \multirow{2}{*}{ CREEA } & Japan & $127,770,750$ & 36,398 & 285 \\
& USA & $301,231,207$ & 200,052 & 664 \\
& China & $1,317,885,000$ & 239,967 & 182 \\
\hline
\end{tabular}

\section{Conclusions}

In this study, we developed a water consumption intensity database that covered all of the goods and services produced in Asia, and estimated the water consumption associated with the economic sectors in nine Asian countries using the AIIO table. This database included all the effects from cradle to gate. From the database, the type of water resources (rainwater, river water, and groundwater) could be distinguished.

Rainwater was identified as the major water resources for goods, with high water consumption in the primary sector. Focusing on the Japanese water consumption intensity, we identified not only domestic consumption but also the effect of importing/exporting produce.

It is expected that database can assist life cycle analysis (LCA) practitioners when performing water footprint assessments in a consistent way, and enable them to meet the requirements of developing international standards (ISO14046). The datasets of water consumption intensities prepared in this study covered all goods and services produced in Asia by considering the site-specific conditions (production technology levels, water demand, etc.). The water consumption intensities of goods and materials imported from other countries were assumed to be the same as those produced in Asia, based on an IO analysis (non-competitive input model). In future studies, the precision of the datasets in this database, the reliability of the water footprint results and the linkage of the supply chain at the global scale need to be considered.

Supplementary Materials: The following are available online at www.mdpi.com/2071-1050/9/8/1351/s1.

Acknowledgments: This research was supported by the Environment Research and Technology Development Fund (S14) of the Ministry of the Environment, Japan. The authors would like to thank the contributor for the data used in this study.

Author Contributions: The text of this manuscript was written by Yuya Ono, with contributions by Young Deuk Kim and Norihiro Itsubo. Data collection, and data analysis was performed by Yuya Ono and Young Deuk Kim. The research was supervised by Norihiro Itsubo. All authors proofread and approved the final manuscript.

Conflicts of Interest: The authors declare no conflict of interest. 


\section{References}

1. Ministry of Economy, Trade and Industry (METI). White Paper on International Economy and Trade in Japan. Available online: http:/ / www.meti.go.jp/report/tsuhaku2008/index.html (accessed on 17 September 2016). (In Japanese)

2. Ministry of Land, Infrastructure, Transport and Tourism (MLIT). Water Resources in Japan. Available online: http:/ / www.mlit.go.jp/tochimizushigen/mizsei/hakusyo/index5.html (accessed on 17 September 2016).

3. Pfister, S.; Koehler, A.; Hellweg, S. Assessing the environmental impacts of freshwater consumption in LCA. Environ. Sci. Technol. 2009, 43, 4098-4104. [CrossRef] [PubMed]

4. Motoshita, M.; Itsubo, N.; Inaba, A. Development of impact factors on damage to health by infectious diseases caused by domestic water scarcity. Int. J. Life Cycle Assess. 2010, 16, 65-73. [CrossRef]

5. Boulay, A.-M.; Bulle, C.; Bayart, J.-B.; Deschênes, L.; Margni, M. Regional characterization of freshwater use in LCA: Modeling direct impacts on human health. Environ. Sci. Technol. 2011, 45, 8948-8957. [CrossRef] [PubMed]

6. Motoshita, M.; Ono, Y.; Pfister, S.; Boulay, A.M.; Berger, M.; Nansai, K.; Tahara, K.; Itsubo, N.; Inaba, A. Consistent characterization factors at midpoint and endpoint relevant to agricultural water scarcity arising from freshwater consumption. Int. J. Life Cycle Assess. 2014. [CrossRef]

7. Verones, F.; Hanafiah, M.M.; Pfister, S.; Huijbregts, M.A.J.; Pelletier, G.J.; Koehler, A. Characterization factors for thermal pollution in freshwater aquatic environments. Environ. Sci. Technol. 2010, 44, 9364-9369. [CrossRef] [PubMed]

8. Van Zelm, R.; Schipper, A.M.; Rombouts, M.; Snepvangers, J.; Huijbregts, M.A.J. Implementing groundwater extraction in life cycle impact assessment: Characterization factors based on plant species richness for the Netherlands. Environ. Sci. Technol. 2011, 45, 629-635. [CrossRef] [PubMed]

9. Hoekstra, A.Y.; Chapagain, A.K.; Aldaya, M.M.; Mekonnen, M.M. The Water Footprint Assessment Manual: Setting the Global Standard. Available online: http://waterfootprint.org/media/downloads/ TheWaterFootprintAssessmentManual_2.pdf (accessed on 17 September 2016).

10. International Organization for Standardization (ISO). ISO 14046:2014 Environmental Management-Water footprint_Principles, Requirements and Guidelines. Available online: http:/ / www.iso.org/iso/catalogue_ detail? csnumber $=43263$ (accessed on 17 September 2016).

11. Boulay, A.M.; Hoekstra, A.Y.; Vionnet, S. Complementarities of water-focused life cycle assessment and water footprint assessment. Environ. Sci. Technol. 2013, 47, 11926-11927. [CrossRef] [PubMed]

12. Manzardo, A.; Mazzi, A.; Loss, A.; Butler, M.; Williamson, A.; Scipioni, A. Lessons learned from the application of different water footprint approaches to compare different food packaging alternatives. J. Clean. Prod. 2015, 112, 4657-4666. [CrossRef]

13. Kobayashi, Y.; Oyasato, N. An Estimation of Embodied Intensity of Water Consumption in Japan based on Input-Output Analysis Method. J. Life Cycle Assess. Jpn. 2008, 4, 359-366. [CrossRef]

14. Ecoinvent. Ecoinvent Version 3. Available online: http:/ /www.ecoinvent.org/ (accessed on 17 September 2016).

15. PE International. LCA Software GaBi. Available online: http://www.thinkstep.co.jp/gabi (accessed on 17 September 2016). (In Japanese)

16. Quantis. Water Database. Available online: http://www.quantis-intl.com/microsites/waterdatabase.php (accessed on 17 September 2016).

17. Water Footprint Network. Water Footprint Statistics (WaterStat). Available online: http://www. waterfootprint.org/?page=files/WaterStat (accessed on 17 September 2016).

18. Lave, L.B.; Elisa, C.-F.; Chris, T.H.; Francis, C.M. Using input-output analysis to estimate economy-wide discharges. Environ. Sci. Technol. 1995, 29, 420-426. [CrossRef]

19. Suh, S.; Huppes, G. Missing Inventory Estimation Tool Using Extended Input-Output Analysis. Int. J. Life Cycle Assess. 2002, 7, 134-140. [CrossRef]

20. Nansai, K.; Moriguchi, Y.; Tohno, S. Compilation and Application of Japanese Inventories for Energy Consumption and Air Pollutant Emissions Using Input-Output Tables. Environ. Sci. Technol. 2003, 37, 2005-2015. [CrossRef] [PubMed]

21. Nansai, K.; Kondo, Y.; Kagawa, S.; Suh, S.; Nakajima, K.; Inaba, R.; Tohno, S. Estimates of Embodied Global Energy and Air-Emission Intensities of Japanese Products for Building a Japanese Input-Output Life Cycle Assessment Database with a Global System Boundary. Environ. Sci. Technol. 2012, 46, 9146-9154. [CrossRef] [PubMed] 
22. Tukker, A.; Huppes, G.; van Oers, L.; Heijung, R. Environmentally Extended Input-Output Tables and Models for Europe, European Commission, Joint Research Centre, Institute for Prospective Technological Studies. Available online: http:/ /ftp.jrc.es/EURdoc/eur22194en.pdf (accessed on 17 September 2016).

23. Blackhurst, M.; Hendrickson, C.; Vidal, J.S. Direct and indirect water withdrawals for U.S. industrial sectors. Environ. Sci. Technol. 2010, 44, 2126-2130. [CrossRef] [PubMed]

24. Kim, Y.D.; Lee, S.H.; Ono, Y.; Lee, S.H. Development of Water Footprint Inventory Using Input-Output Analysis. J. Korea Water Resour. Assoc. 2013, 46, 401-412. [CrossRef]

25. Ono, Y.; Motoshita, M.; Itsubo, N. Development of water footprint inventory database on Japanese goods and services distinguishing the types of water resources and the forms of water uses based on input-output analysis. Int. J. Life Cycle Assess. 2015, 20, 1456-1467. [CrossRef]

26. Lenzen, M. Understanding virtual water flows: A multi-region input-output case study of Victoria. Water Resour. Res. 2009, 45, W09416. [CrossRef]

27. Zhao, X.; Yang, H.; Yang, Z.; Chen, B.; Qin, Y. Applying the Input-Output Method to Account for Water Footprint and Virtual Water Trade in the Haihe River Basin in China. Environ. Sci. Technol. 2010, 44, 9150-9156. [CrossRef] [PubMed]

28. Exiobase. The Global Resource Footprint of Nations. Available online: http:/ /www.exiobase.eu/ (accessed on 17 September 2016).

29. Water Footprint Network. The Water Footprint Assessment Manual: Setting the Global Standard. Available online: http:/ / www.waterfootprint.org/?page=files/home (accessed on 17 September 2016).

30. United Nations Statistics Division. System of Environmental-Economic Accounting for Water (SEEA-W). Available online: http:/ / unstats.un.org/unsd/envaccounting/seeaw (accessed on 17 September 2016).

31. Institute of Developing Economies, Japan External Trade Organization (IDE-JETRO). Asain International Input-Output Table 2005; Institute of Developing Economies, Japan External Trade Organization (IDE-JETRO): Tokyo, Japan, 2013.

32. Leontief, W. Environmental Repurcussions and Economic Structure-Input-Output Approach. Rev. Econ. Stat. 1970, 52, 262-271. [CrossRef]

33. Leontief, W.; Strout, A. Multiregional Input-Output Analysis; Macmillan: London, UK, 1963.

34. Mekonnen, M.M.; Hoekstra, A.Y. The Green, Blue and Grey Water Footprint of Crops and Derived Crop Products. 2010. Value of Water Research Report Series No. 47. Available online: http:/ /www.waterfootprint. org/Reports/Report47-WaterFootprintCrops-Vol1.pdf (accessed on 17 September 2016).

35. Food and Agriculture Organization of the United Nations. Land \& Water. Available online: http:/ /www.fao. org/land-water/databases-and-software/climwat-for-cropwat/en/ (accessed on 17 September 2016).

36. Food and Agriculture Organization of the United Nations. CropWat. Available online: http:/ /www.fao.org/ nr/water/infores_databases_cropwat.html (accessed on 17 September 2016).

37. Food and Agriculture Organization of the United Nations. FAOSTAT. Available online: http://www.fao. org/faostat/en/\#home (accessed on 17 September 2016).

38. Food and Agriculture Organization of the United Nations. Global Forest Resources Assessment (FRA) 2005-Global Tables Designated Functions of Forest-Primary Function 2005. Available online: http: / / www.fao.org/forestry/32035/en (accessed on 17 September 2016).

39. United States Department of Agriculture (USGS). 2008 Farm and Ranch Irrigation Survey. Available online: http://www.agcensus.usda.gov/Publications/2007/Online_Highlights/Farm_and_ Ranch_Irrigation_Survey (accessed on 17 September 2016).

40. Food and Agriculture Organization of the United Nations. AQUASTAT. Available online: http://www.fao. $\mathrm{org} / \mathrm{nr} /$ water/aquastat/data/query/results.html (accessed on 17 September 2016).

41. Tukker, A.; Bulavskaya, T.; Giljum, S.; de Koning, A.; Lutter, S.; Simas, M.; Stadler, K.; Wood, R. The Global Resource Footprint of Nations. Carbon, Water, Land and Materials Embodied in Trade and Final Consumption Calculated with EXIOBASE 2.1. Available online: http:/ / www.truthstudio.com/content/ CREEA_Global_Resource_Footprint_of_Nations.pdf (accessed on 17 September 2016).

(C) 2017 by the authors. Licensee MDPI, Basel, Switzerland. This article is an open access article distributed under the terms and conditions of the Creative Commons Attribution (CC BY) license (http:// creativecommons.org/licenses/by/4.0/). 